\title{
中性子反射率によるソフトマテリアルの表面・界面構造解析
}

\author{
高原 淳 ${ }^{1,2}$ ・ 小林 元康 ${ }^{2}$ \\ '九州大学先導物質化学研究所 寀819-0395 福岡市西区元岡 744 \\ ${ }^{2}$ JST ERATO 高原ソフト界面プロジェクト 恶819-0395 福岡市西区元岡 744
}

（2012 年 2 月 10 日受付；2012 年 3 月 8 日掲載決定）

\section{Analyses of Surface and Interfaces of Soft Materials by Neutron Reflectivity}

\author{
Atsushi TAKahara ${ }^{1,2}$ and Motoyasu Kobayashi ${ }^{2}$ \\ ${ }^{1}$ Institute for Materials Chemistry and Engineering, Kyushu University, 744 Motooka, Nishi-ku, Fukuoka, Fukuoka 819-0395 \\ ${ }^{2}$ JST ERATO Takahara Soft Interfaces Project, 744 Motooka, Nishi-ku, Fukuoka, Fukuoka 819-0395
}

(Received February 10, 2012 ; Accepted March 8, 2012)

\begin{abstract}
During the last 20 years neutron reflectivity has emerged as a powerful and important technique for the study of soft materials surfaces and interfaces. The selectivity and sensitivity afforded by deuterium/hydrogen labeling makes the technique particularly attractive for application to characterization of surface and interface, but also water/solid interface. This review provides a brief introduction of applications of neutron reflectivity to analyses of soft materials surface and interfaces.
\end{abstract}

KEYWORDS : neutron reflectivity, soft material, surface structure, buried interface, polymer brush

\section{1.は じめに}

X 線や中性子は，物質の表面に当たると反射する。表 面が平滑であればよく反射するが，表面に凹凸があると 散乱や屈折のため反射は弱くなる。これは, 光の反射と 同じである。

たとえば，シリコンウエハーなどの基板表面に調製し た薄膜に X 線や中性子を当て, 入射角と反射角が同じ 角度になる対称反射の条件で反射強度を測定する。この 場合膜表面からの反射と, 膜/基板との界面からの反射 が干渉するため, 入射角の関数として反射率（反射中強 度/入射強度）の振動が観測される。この反射率の入射 角（あるいは散乱べクトル）依存性を解析することで, 膜の厚さ，表面の粗さ，膜厚方向の組成分布などを明ら かにすることができる。

このような表面からの反射率で物質の表面・界面構造 を解析する方法が反射率測定法である。特に中性子を使 う場合を，中性子反射率測定法（Neutron Reflectivity：

E-mail : takahara@cstf.kyushu-u.ac.jp
NR）とよぶ。中性子は軽元素や磁性体に対する感度が 高く，X 線に比べて水素に関する情報を選択的に識別す る能力が高いため, 特に水素を重水素に置換可能な有機 高分子材料などのソフトマテリアル薄膜の構造解析で注 目を集めている。また基板に中性子の透過性の高い $\mathrm{Si}$ などを用いて，基板側から中性子を入射し，重水素化溶 媒を用いることにより固/液の界面などの「埋もれた界 面」の構造解析が可能となる。

このような薄膜や埋もれた界面の構造解析は, 薄膜構 造の基礎学問のみならず，種々の材料の高機能化と関連 してきわめて重要である。

\section{2. 反射率測定の原理 ${ }^{1 \sim 3)}$}

NR 測定は，積層構造を有する薄膜試料について，各 層の組成およびそれらの形成する界面の粗さや拡散を評 価するための手法である。試料表面から埋もれた界面ま での薄膜深さ方向の構造を, 非破壊で測定することがで きる。NR 測定では，入射角と同じ角度で反射された中 性子を観測する。反射による移行運動量は, 散乱べクト ル $q$ として, 次式で表される。 


$$
q=\frac{4 \pi \sin \theta}{\lambda}
$$

ここで， $\lambda$ は中性子の波長， $\theta$ は入射角である。測定 の模式図を Fig. 1 に示す。特に物質表面に対して垂直方 向成分を $q_{\mathrm{z}}$ と表記する。

$\mathrm{NR}$ 測定における物質の屈折率 $n$ は, 次式で表され る。

$$
n \approx 1-\left(\frac{\lambda^{2}}{2 \pi}\right)(b / V)
$$

ここで，入は入射中性子の波長， $(b / V)$ は散乱長密度 (Scattering length density, SLD) である。中性子の散乱の 程度を表す量を散乱長 $(b)$ といい，物質を構成する原 子や分子の占める体積 $(V)$ で割った值を散乱長密度と いう。屈折率が試料の電子密度に依存する X 線と異な り, 物質の中性子に対する屈折率は, 散乱長密度に依存 した值となる。散乱長密度は, 元素に依存するのみなら ず，その同位体によっても非常に異なった值を示す。こ の性質を利用して，高分子などの有機材料では，しばし ば重水素化によるラベリングが行われる。これにより, $\mathrm{X}$ 線ではコントラストが小さく識別不可能な混合試料に ついても，中性子反射率では明確に識別することが可能 となる。

多くの物質の中性子に対する屈折率は, 1 よりもわず かに小さな值であるために，平坦かつ平滑な物質表面 に，全反射臨界角よりも浅い角度で入射した中性子は物 質の外部で光学的な全反射を起こす。入射角を臨界角以 上にした時には，入射された中性子は物質表面で反射さ れるものと透過されるものに分かれる。この領域では, 反射強度は $q^{-4}$ に比例して急激に減少する。透過した波 は, 物質中において, 密度の異なる界面で再び反射波と 透過波に分かれる。各界面にて反射した波は互いに干渉 し, Kiessig フリンジと呼ばれる干渉振動を生じる。こ の振動は, 薄膜の散乱長密度および膜厚を反映したもの となる。Fig. 2 に種々の膜厚 $d$ を有するシリコン基板上 の高分子薄膜からの反射率曲線を示す。膜厚の増加とと もにフリンジの周期が短くなる。

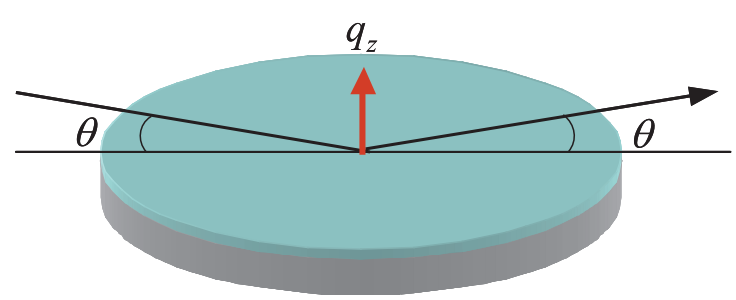

Fig. 1. (color online). Schematic representation of the principle of NR.
一方，薄膜の表面や界面に粗さが存在すると，その層 からの反射が減少し, 反射曲線に変化が現れる。界面で の原子の相互拡散や密度勾配が存在する場合も, 拡散領 域は粗さとして解析される。界面における組成分布は, 深さの関数として，一般にガウス分布で表される。界面 における組成分布が標準偏差 $\sigma$ で表される粗い界面か らの反射率 $R(q)$ は次式で表される。

$$
R(q)=R_{F}(q) \exp \left(-q^{2} \sigma^{2}\right)
$$

ここで, $R_{F}(q)$ は粗さのない理想界面からの Fresnel 反射率である。このように，反射率測定では，多層膜の 各層からの反射およびその干渉を測定することで，多層 膜の各層の膜厚や組成，また，層間の粗さに関する情報
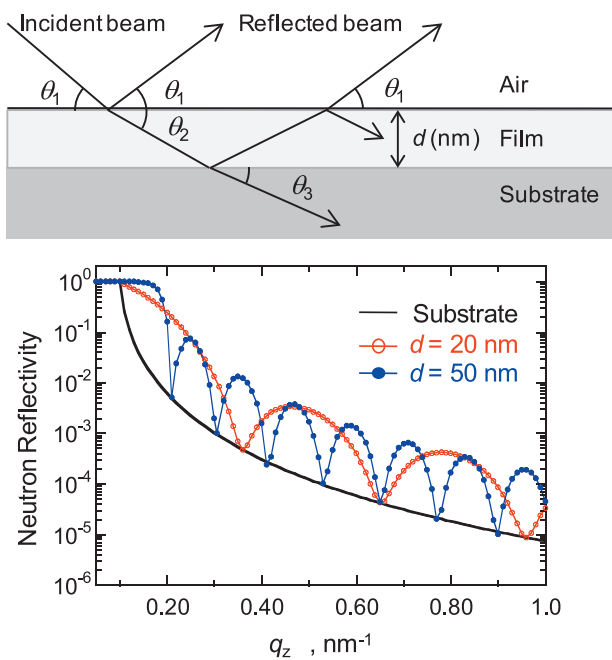

Fig. 2. (color online). Schematic representation of the beam path in a film with thickness, $d$, on a substrate and reflectivity profiles calculated for uniform films of two different values of $d$ as compared with the bare substrate Fresnel reflectivity. The $b / V$ of the films and the substrate are fixed at $6.05 \times 10^{10} \mathrm{~cm}^{-2}$ and $2.15 \times 10^{10} \mathrm{~cm}^{-2}$, respectively.
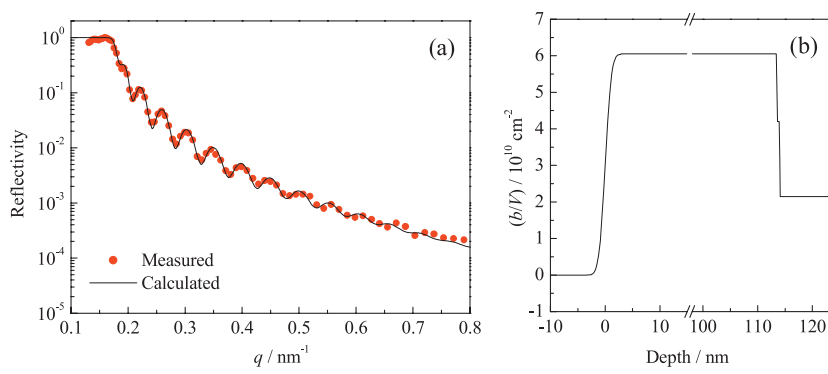

Fig. 3. (color online). (a) NR profile and fitting curve of ca. $110 \mathrm{~nm}$ thick d-PS38k film. Solid curve is the result of model fit corresponding to the depth profile model of $b / V$ shown in (b). 
を得ることができる。

このような NR 測定のために, 国内には原子炉の冷中 性子を用いた, SUIREN, MINE（JRR-3）年，パルス中性 子源を用いた SOFIA (J-PARC) ${ }^{5)}$ (KENS, J-PARCで活 躍していた ARISA ${ }^{6}$ の後継装置) が稼働している。装置 の詳細に関しては原報を参考にされたい。

Fig. 3 は, シリコン基板上の重水素化ポリスチレン （数平均分子量 $M_{\mathrm{n}}=63000 ） （ \mathrm{~d}-\mathrm{PS} 38 \mathrm{k}$ ） 薄膜の NR プロ ファイルおよび解析曲線, また, 解析に用いた薄膜深さ 方向の散乱長密度プロファイルを示す。この測定結果よ り算出された d-PS38k の散乱長密度は $6.05 \times 10^{10} \mathrm{~cm}^{-2}$ であった。また, 散乱長密度プロファイルから明らかな ように, d-PS38k のみの薄膜では, 空気層から d-PS38k 薄膜層へと変化する薄膜表面, および d-PS38k 薄膜層か らシリコン酸化膜抒よびシリコン基板へと変化する基板 界面ともに鋭い散乱長密度の変化が起こっており, 薄膜 表面および基板との界面ともに平滑で, 組成が均一な状 態にあることが分かる。

\section{3. ジブロック共重合体薄膜の構造解析}

ジブロック共重合体は二つのブロックの体積分率がほ ほ等しい場合には, ラメラ状のミクロ相分離構造を形成 する。Fig. 4 はシリコン基板上に成膜し，十分に熱処理 した末端カルボン酸を導入した対称重水素化ポリスチレ ンーポリメタクリル酸メチルジブロック共重合体（P (dSt-b-MMA)-COOH, $M_{\mathrm{n}}=25.2 \mathrm{k}, \mathrm{PS}$ 分率 $=41.6 \%$ ) 薄 膜の NR 曲線とそれに対応する散乱長密度プロファイル (挿入図) である。測定は MINE で行った。この系はラ メラ構造を形成し, NR 曲線には膜厚に対応する干渉と 長周期（約 $20 \mathrm{~nm}$ ）に対応するブラッグピークが重なっ たものが観測される。特にこの結果からは空気界面に表
面エネルギーの相対的に低い PS が，また基板界面には 表面エネルギーの相対的に高い PMMA が濃縮されてい ることが明らかである。このようにNRは埋もれた界面 の構造評価にきわめて有効である。

\section{4.（有機/無機）ハイブリッド薄膜の構造解 析 ${ }^{7,8)}$}

(有機/無機) ハイブリッド薄膜は電子材料, 光学材料 などでの応用が期待されている。穂坂らはポリスチレン 薄膜の熱的な安定性の向上のためオクタシクロペンチル オクタヘドラルシルセスキオキサン (CpPOSS) とのハ イブリッド薄膜を調製した。CpPOSS/PS 薄膜の媣さ方 向における CpPOSS 分布構造はXPS 測定では検討が困 難であった, 基板界面付近における構造の評価を目的と して, NR 測定を行った。試料は, PS マトリックスと CpPOSS の散乱長密度のコントラストを増大するため, PS の重水素化物である d-PS38k を用いて調製した。測 定試料としては, 膜厚約 $110 \mathrm{~nm}$ の d-PS38k 薄膜および CpPOSS/d-PS38k（10/90，w/w）薄膜を用いた。また, 散乱長密度を, 空気層は $0.00 \times 10^{10} \mathrm{~cm}^{-2}$, シリコン基 板上の酸化膜は $4.20 \times 10^{10} \mathrm{~cm}^{-2}$, シリコン基板は $2.15 \times 10^{10} \mathrm{~cm}^{-2}$ として解析を行った。一方, CpPOSS の 散乱長密度としては, CpPOSS の密度 $1.33 \mathrm{~g} / \mathrm{cm}^{3}$ および 散乱長 $99.4 \mathrm{fm}$ を用いて算出した $0.82 \times 10^{10} \mathrm{~cm}^{-2}$ を用い た。

Fig. 5 は CpPOSS/d-PS38k（10/90, w/w）薄膜の NR 曲線抢よび解析曲線, また, 解析に用いた薄膜梁さ方向 の散乱長密度プロファイルを示す。CpPOSS/d-PS38k 薄 膜の散乱長密度プロファイルでは, 空気層から薄膜層へ と変化する薄膜表面の組成変化が, d-PS38k 薄膜と比較 すると，緩やかになっていることが分かる。これは,

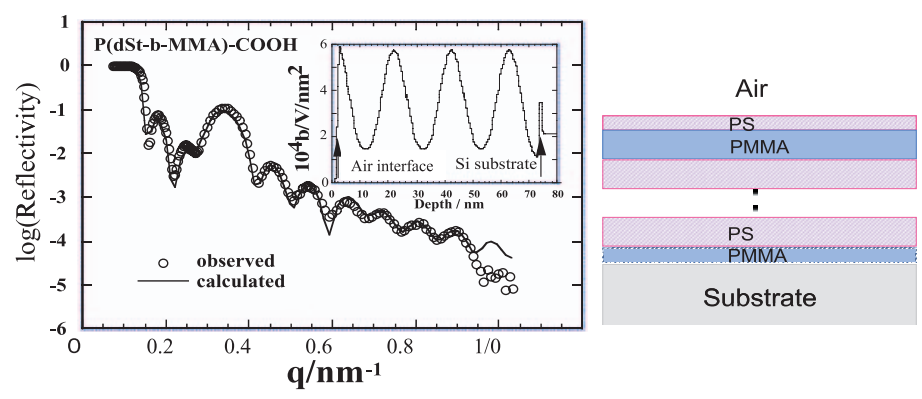

Fig. 4. (color online). NR profile and fitting curve of ca. $70 \mathrm{~nm}$ thick $\mathrm{P}$ (dSt-b-MMA)-COOH diblock copolymer film. Solid curve is the result of model fit corresponding to the depth profile model of $b / V$ shown in inserted figure. Right side is a schematic model of thin film. Blank area in the model was also filled with alternating layers of PS and PMMA. 
CpPOSS が薄膜表面へ濃縮したことによる, 散乱長密度 の低い表面層の形成を表すものと考えられ，XPS 測定 の結果を支持するものである。また, 薄膜内部の散乱長 密度は $5.75 \times 10^{10} \mathrm{~cm}^{-2}$ で, d-PS38k 薄膜よりも低い值と なっている。この散乱長密度から算出された薄膜内部の CpPOSS の体積分率は 5.7\% で, CpPOSS の添加量から 算出された体積分率である $8.1 \%$ と比較すると, 約 70\% の值である。この結果は, XPS 測定から算出された, 薄膜内部の領域における CpPOSS 濃度とよく一致する 值となった。このことから，薄膜内部の領域における CpPOSS 濃度は, CpPOSS 添加濃度をわずかに下回る值 であると結論づけることができる。また, 薄膜層からシ リコン酸化膜およびシリコン基板へと変化する基板界面 においては, 散乱長密度の低い層の形成が確認された。 これは, CpPOSS の基板界面への濃縮を表す結果であ る。薄膜層から CpPOSS 濃縮層への散乱長密度の変化 は緩やかに起こって抢り, CpPOSS 濃縮層と薄膜層の間 は粗い界面が形成されていることが示唆されている。

以上のように, CpPOSS/d-PS38k 薄膜の NR 測定で は, CpPOSS が薄膜の表面および基板との界面の双方に 濃縮する傾向を有していることが明らかとなった。 CpPOSS の基板界面への濃縮の駆動力としては, PS と 比較して, Si-O 骨格を有する CpPOSS と基板との親和 性が高いこと, また, CpPOSS が界面に扔けるエントロ ピー的な不利益を受けにくい低分子量成分であることが 予想できる。CpPOSS の基板界面への濃縮は, 基板と薄 膜との親和性や，基板界面の粗さを変化させうるもの で, この CpPOSS の界面濃縮も, PS 薄膜の dewetting の 抑制に対して大きく寄与している。
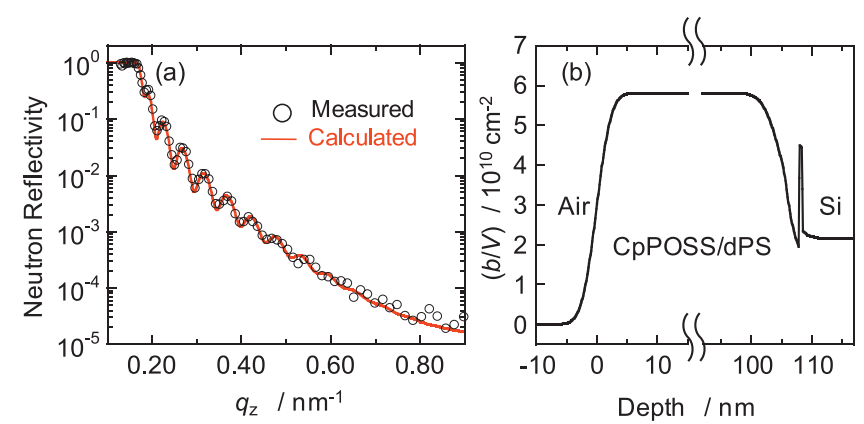

Fig. 5. (color online). (a) NR profile and fitting curve of ca. $110 \mathrm{~nm}$ thick CpPOSS/d-PS38k (10/90, w/w) film. Solid curve is the result of model fit corresponding to the depth profile model of $b / V$ shown in (b).

\section{5. 末端 POSS 修飾ポリスチレンハイブリッド 薄膜の構造解析 ${ }^{9}$}

CpPOSS とPS の相溶性を高め, 膜の平滑性を向上し, より効果的に熱的安定性を向上させるために PS-Cp POSS $/ \mathrm{PS}$ 薄膜を調製し, 平滑な表面を有する PS 薄膜を 調製した。薄膜の構造を解明するために NR 測定により PS-CpPOSS/PS ブレンド薄膜の深さ方向の組成分布評価 を行った。PS-CpPOSS とPS マトリクスの散乱長密度 $(b / V)$ のコントラストを明確化するためにdPS-POSS を 調製し, dPS-CpPOSS2.9k/PS44k（32/68, w/w）ブレン ド薄膜を試料とした。

深さ方向の $b / V$ を仮定し, モデル計算より解析した 反射率プロファイルを Fig. 6 に示す。PS および dPS の $b / V$ 值はそれぞれ $1.4 \times 10^{10} \mathrm{~cm}^{-2}$ および $6.1 \times 10^{10} \mathrm{~cm}^{-2}$ とし, 空気層, シリコン基板の自然酸化膜, シリコン基 板の $b / V$ 值はそれぞれ $0.00 \times 10^{10} \mathrm{~cm}^{-2}, 4.20 \times 10^{10}$ $\mathrm{cm}^{-2}, 2.15 \times 10^{10} \mathrm{~cm}^{-2}$ として解析を行った。バルクの $b / V$ 值は $2.17 \times 10^{10} \mathrm{~cm}^{-2}$ と PS と比較して若干大きな值 を示した。これは dPS-CpPOSS が薄膜梁さ方向に分散 しているためであると考えられる。薄膜表面に扔ける $b / V$ 值は, XPS 測定より明らかとなったPS-CpPOSS の 表面濃縮の寄与により, 膜内部と比較して著しく高い值 を示した。これに加えて, 基板界面付近においても $b / V$ が増加しており, dPS-CpPOSS2.9k は PS44k 薄膜中にお いて表面掞よび界面の双方に濃縮する傾向を有している ことが明らかとなった。このような $\mathrm{dPS}-\mathrm{PCpOSS}$ の界 面濃縮は，上述のように dPS-CpPOSS2.9k が PS44k に対 してエントロピー的な制限を受けにくい低分子量成分で あることに起因するものと考えられる。

dPS-CpPOSS2.9k の表面・界面偏析が PS 成分の重水 素化にともなう同位体効果によるものではないことを確

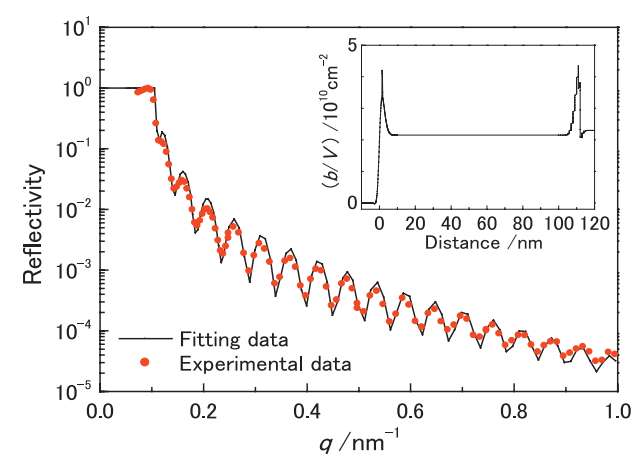

Fig. 6. (color online). NR profile from 118-nm thick dPSCpPOSS2.9k/PS44k thin film annealed at $393 \mathrm{~K}$ for $3 \mathrm{~h}$. The inset shows the scattering length density $(b / V)$ profile used to calculate the reflectivity profile as the solid line. 


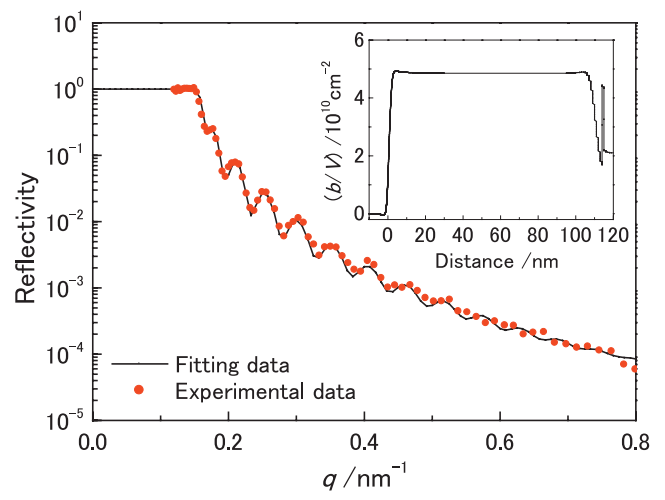

Fig. 7. (color online). NR profile from 118-nm thick PSCpPOSS2.5k/dPS38.5k thin film annealed at $393 \mathrm{~K}$ for $3 \mathrm{~h}$. The inset shows the scattering length density $(b / V)$ profile used to calculate the reflectivity profile as the solid line.

認するために, 軽水素と重水素のコントラストを反転さ せてNR 測定を行った。測定には, ARISA 反射率計を 用い, PS-CpPOSS $2.5 \mathrm{k} / \mathrm{dPS} 38.5 \mathrm{k}(28 / 72, \mathrm{w} / \mathrm{w})$ ブレン ド薄膜を試料とした。

深さ方向の $b / V$ を仮定し解析した反射率プロファイ ルを Fig. 7 に示す。dPS-CpPOSS/PS ブレンド薄膜の場 合とは対照的に, バルクの $b / V$ は $4.89 \times 10^{10} \mathrm{~cm}^{-2}$ と $\mathrm{dPS}$ と比較して若干低い值を示し, また表面および基板 界面における $b / V$ は $1.38 \times 10^{10} \mathrm{~cm}^{-2}$ と著しく低い值を 示した。すなわち PS-POSS は薄膜内部に分散して存在 するものの, その一部は表面・界面へ選択的に濃縮して いることが確認された。このようなPS-CpPOSS の界面 濃縮は基板と薄膜の親和性や基板界面のラフネスを変化 させうるものであり, 接触点の固定化をもたらすことが 期待される。すなわち, PS-CPPOSS 添加による薄膜の dewetting 抑制には, PS-CpPOSS の表面および界面濃縮 にともなう表面・界面の改質効果が大きく寄与してい る。

\section{6. 高分子ブラシ水界面からの中性子反射率曲 線}

鎖末端の一方が固体表面・界面に化学結合や吸着によ り固定化され，かつ隣接鎖同士が接触するほど密に存在 している高分子集合体を「表面グラフトポリマー」また は「ポリマーブラシ」と呼ぶ ${ }^{10)}$ 。このポリマーブラシは 平面基板の表面・界面のみならず, ブロック共重合体が 形成したミセルや相分離構造の界面や, 溶液中のコロイ ド粒子の界面にも存在し, その粒径や形状を決定づける 重要な役割を果たしている。そのため, 固体表面と外部 媒体との界面におけるポリマーブラシ鎖の広がりや膨 潤, 収縮挙動などについて多くの研究が行われてい

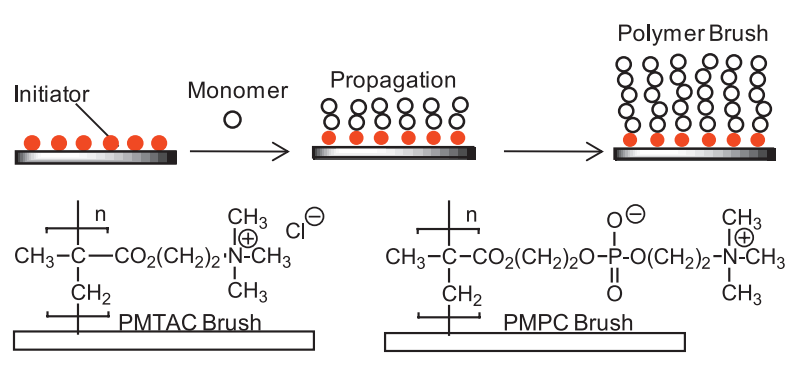

Fig. 8. (color online). Chemical structure of polymer brushes and preparation scheme for surface-initiated contolled radical polymerization.

\section{る $^{10,11)}$ 。}

ポリマーブラシの調製法として表面開始重合法がよく 用いられている。たとえば, Fig. 8 のように基板表面に 臭化アルキルシラン化合物を化学的に吸着させ, 重合開 始種を固定化する。この基板をメタクリル酸エステルな どのモノマー溶液に浸し, 臭化銅などの触媒を適切な条 件で作用させると基板表面の臭化アルキルが起点となっ てモノマーが連鎖的に反応（原子移動ラジカル重合） し, きわめて均一でグラフト密度の高いポリマーブラシ が得られる。

このポリマーブラシを良溶媒中に浸漬するとブラシ層 内は高分子濃厚溶液状態であるため高い浸透圧が発生す る。個々の高分子鎖は膨潤するが高密度にグラフトされ ているがゆえに 3 次元に等方的に広がることができず, 基板平面に対して垂直方向に伸長した分子形態をと る ${ }^{11)}$ 。これが垂直荷重に対する強い反発力を生み, ブラ シ表面同士を接近させても対向するブラシ鎖同士の相互 貫入が抑制されるために，ブラシ界面の摩擦抵抗はきわ めて低くなる。

この構造を分析するために本研究では NR 測定を試み た ${ }^{12,13)}$ 。中性子線は優れた透過性を有するために固体/ 液体界面の反射率測定が可能であり, 重水素と軽水素の 中性子散乱長密度の差を利用して溶液中の高分子電解質 ブラシ薄膜の膨潤・収縮挙動を解析することができる。

Fig. 9 はカチオン性高分子電解質であるポリ（2-(メ夕 クリロイルオキシ) エチルトリメチルアンモニウムクロ リド）（PMTAC）（Fig.8）ブラシの重水および $1.0 \mathrm{M}$ $\mathrm{NaCl}$ 重水溶液界面における $\mathrm{NR}$ 曲線と対応する中性子 散乱長密度分布（SLD）である。本実験では石英基板表 面に調製したPMTAC ブラシと重水との界面に種々の角 度で中性子ビームを入射し, 反射率曲線を得た。この NR 曲線をもとに基板と垂直方向の SLDを計算し, 重 水中における PMTAC ブラシの膨潤膜厚を求めると 75 $\mathrm{nm}$ であった。一方, $\mathrm{NaCl}$ 重水溶液中では $38 \mathrm{~nm}$ であっ た。これは水溶液中の塩強度が増大することでカチオン 

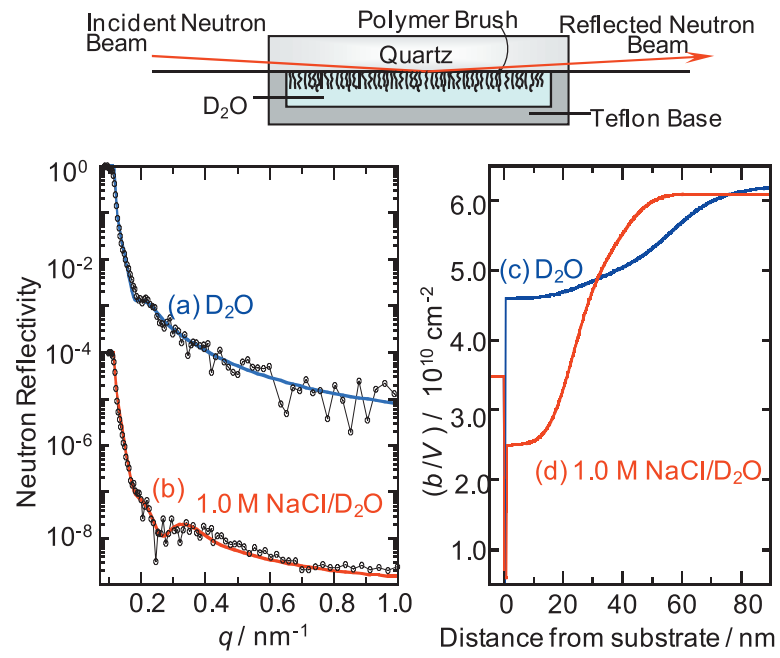

Fig. 9. (color online). NR profiles of (a) PMTAC brush/ $\mathrm{D}_{2} \mathrm{O}$, (b) PMTAC brush/1.0 $\mathrm{M} \mathrm{NaCl}$ in $\mathrm{D}_{2} \mathrm{O}$, and (c)-(d) their corresponding neutron SLD profiles along with the distance from quartz surface, respectively. Scattering vector $q=(4 \pi / \lambda) \sin \theta$.

間の静電斥力相互作用が弱められ, 比較的伸長していた 分子鎖が収縮した構造へ変化したためである。

一方，ポリ（2-メタクリロイルオキシエチルホスホリ ルコリン）（PMPC）（Fig. 8）ブラシ鎖は塩存在下でも 収縮せず，ほほ伸びきり鎖の状態を維持していることが NR 測定から明らかとなった（詳細デー夕は省略）。 PMPC 分子鎖の広がりが塩濃度に依存しないことは松田 らが動的光散乱測定 ${ }^{14)}$ から, 菊地らが小角 $X$ 線散乱 ${ }^{15)}$ から見出している。PMPC は生体細胞膜表面のリン脂質 極性基に着目して設計された生体適合性電解質ポリマー であり, ホスホリルコリン基間の静電相互作用がきわめ て弱く, 特異な水和構造を有していることが塩濃度非依 存性の要因と考えられている。

\section{7.おわりに}

以上，筆者らの代表的な研究例をあげてきたように中 性子反射率測定は埋もれた界面の構造評価にきわめて有 効である。このほかにも表面層への低分子成分の濃 縮 ${ }^{16)}$, 積層膜界面での分子拡散 ${ }^{17)}$, 超臨界二酸化炭素中 でのフッ素系高分子の膨潤挙動 ${ }^{18)}$, 水面上高分子単分子 膜の構造解析 ${ }^{19)}$ の例が報告されている。

高強度の中性子源である J-PARC における SOFIA の 設置は, 中性子の特徴である高い物質透過性と水素原子 の識別能を活用し, ソフトマターに内在する界面の構造 形成キネティックスや界面への分子吸着キネティックス の実時間解析, 界面の 3 次元構造解析, 電場や光などの
外場に対する界面応答, 界面の動的摇らぎ解析などを行 い界面ダイナミクスという新たな研究領域を開拓するも のと期待されている。

\section{文献}

1) T. Imae, T. Kanaya, M. Furusaka and N. Torikai : "Neutrons in Soft Matter" (Wiley, Hoboken, 2011).

2) T.P. Russell : Materials Science Reports, Materials Science Reports, 5, 171 (1999).

3) 入門講座「中性子反射率測定」, 波紋, Vol. 18-Vol. 20 (2008-2010).

4) 山崎 大, 日野正裕: 波紋, 19, 34 (2009).

5) N.L. Yamada, N. Torikai, K. Mitamura, H. Sagehashi, S. Sato, H. Seto, T. Sugita, S. Goko, M. Furusaka, T. Oda, M. Hino, T. Fujiwara, H. Takahashi and A. Takahara: Euro. Phys. J. Plus. 126, 108 (2011).

6) N. Torikai, M. Furusaka, H. Matsuoka, Y. Matsushita, M. Shibayama, A. Takahara, M. Takeda, S. Tasaki and H. Yamaoka: Appl. Phys. A, 74 [Suppl.] S264-S266 (2002).

7) N. Hosaka, H. Otsuka, N. Torikai and A. Takahara : Langmuir 23, 902 (2007).

8) N. Hosaka, H. Otsuka, M. Hino and A. Takahara : Langmuir 24, 5766 (2008).

9) K. Miyamoto, N. Hosaka, M. Kobayashi, H. Otsuka, N. Yamada, N. Torikai and A. Takahara : Polym. J. 39, 1247 (2007).

10) R.C. Advincula, W.J. Brittain, K.C. Caster and J. Rühe : Polymer Brushes (Wiley-VCH, Weinheim, 2004).

11) Y. Tsujii, K. Ohno, S. Yamamoto, A. Goto and T. Fukuda: Adv. Polym. Sci. 197, 1 (2006).

12) M. Kobayashi, Y. Terayama, N. Hosaka, M. Kaido, A. Suzuki, N. Yamada, N. Torikai, K. Ishihara and A. Takahara : Soft Matter 3, 740 (2007).

13) M. Kobayashi, K. Mitamura, M. Terada, N.L. Yamada and A. Takahara: J. Phys. : Conf. Ser. 272, 012019 (2011).

14) Y. Matsuda, M. Kobayashi, M. Annaka, K. Ishihara and A. Takahara : Langmuir 24, 8772 (2008).

15) M. Kikuchi, Y. Terayama, T. Ishikawa, T. Hoshino, M. Kobayashi, H. Ogawa, H. Masunaga, J. Koike, M. Horigome, K. Ishihara and A. Takahara : Polym. J. 44, 121 (2012).

16) K. Tanaka, T. Kajiyama, A. Takahara and S. Tasaki : Macromolecules 35, 4702 (2002).

17) D. Kawaguchi, K. Tanaka, T. Kajiyama, A. Takahara and S. Tasaki : Macromolecules 36, 1235 (2003).

18) T. Koga, P. Gin, H. Yamaguchi, M.K. Endoh, M. Asada, L. Sendogdular, M. Kobayashi, A. Takahara, B. Akgun, S.K. Satija and T. Sumi : Polymer 52, 4331 (2011).

19) E. Mouri, P. Kaewsaiha, K. Matsuomoto, H. Matsuoka and N. Torikai : Langmuir 20, 10604 (2004). 